\title{
Alterations to Arbuscular Mycorrhizal Fungal community composition is driven by warming at specific elevations
}

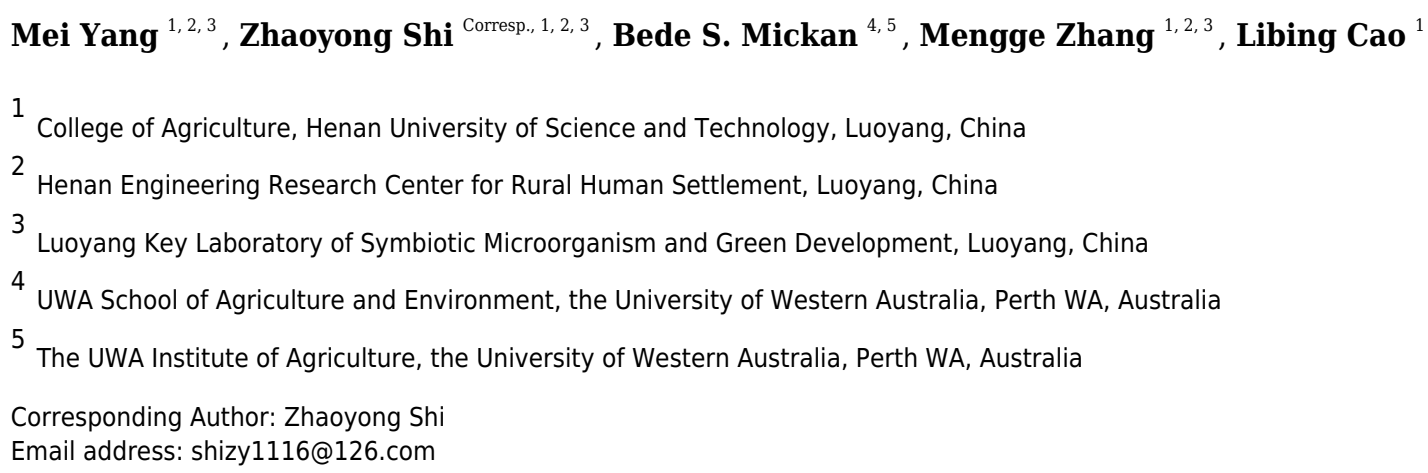

Background. Global warming can alter plant productivity, and community composition which has consequences for soil-plant associated microorganisms. Arbuscular mycorrhizal fungi (AMF) are distributed widely and form symbiotic relationships with more than $80 \%$ of vascular plants and play a key role in nutrient cycling processes at the ecosystem scale. Methods. A simulated warming experiment at multiple elevations ( 3000 m, 3500 m, 3800 $\mathrm{m}$, and $4170 \mathrm{~m}$ ) was conducted utilizing an in-situ open-top chamber (OTC) for exploring the effect of global warming on AMF community structure in the Qinghai-Tibet Plateau (QTP). This region has been identified as one of the most sensitive areas to climatic changes. Soil DNA was extracted and sequenced using next the Mi-Seq platform for diversity profiling. Results. AMF richness was higher under the simulated warming chamber, however this only occurred in the elevation of $3500 \mathrm{~m}$. Warming did not alter other AMF alpha diversity indices (e.g. Shannon, Ace, and Simpson evenness index). Glomus and Acaulospora were the dominate AMF genera as assessed through their relative abundance and occurrence in control and warming treatments at the different elevations. Conclusion. Warming changed significantly AMF community. The effects of warming on AMF community structure varied depend on elevations. Moreover, the occurrences of AMF in different genera were also presented the different responses to warming in four elevations. 


\section{Alterations to Arbuscular Mycorrhizal Fungal community 2 composition is driven by warming at specific elevations} 3

4 Mei Yang ${ }^{1,2,3}$, Zhaoyong Shi ${ }^{1,2,3}$, Bede S. Mickan ${ }^{4,5}$, Mengge Zhang ${ }^{1,2,3}$, Libing Cao ${ }^{1}$ 5

$6{ }^{1}$ College of Agriculture, Henan University of Science and Technology, Luoyang 471023, China

$7 \quad{ }^{2}$ Henan Engineering Research Center for Rural Human Settlement, Luoyang 471023, China

$8{ }^{3}$ Luoyang Key Laboratory of Symbiotic Microorganism and Green Development, Luoyang 9 471023, China

$10{ }^{4}$ UWA School of Agriculture and Environment, the University of Western Australia, Perth WA 6009, 11 Australia

$12{ }^{5}$ The UWA Institute of Agriculture, the University of Western Australia, Perth WA 6009, Australia 13

14 Corresponding Author:

15 Zhaoyong Shi

16 263\# Kaiyuan Road, Luoyang, Henan Province, 471023 P.R China

17 Email address: shizy1116@126.com

18 
19

20

21

22

23

24 25

26

27 28

29

30 31

32

\section{ABSTRACT}

Background. Global warming can alter plant productivity, and community composition which has consequences for soil-plant associated microorganisms. Arbuscular mycorrhizal fungi $(\mathrm{AMF})$ are distributed widely and form symbiotic relationships with more than $80 \%$ of vascular plants and play a key role in nutrient cycling processes at the ecosystem scale.

Methods. To this end, a simulated warming experiment at multiple elevations $(3000 \mathrm{~m}, 3500 \mathrm{~m}$, $3800 \mathrm{~m}$, and $4170 \mathrm{~m}$ ) was conducted utilizing an in-situ open-top chamber (OTC) for exploring the effect of global warming on AMF community structure on the Qinghai-Tibet Plateau (QTP). Soil DNA was extracted and sequenced using the Mi-Seq platform for diversity profiling of the AMF community.

Results. AMF richness was higher under the simulated warming, however this only occurred in the elevation of $3500 \mathrm{~m}$. Warming did not alter other AMF alpha diversity indices (e.g. Shannon, Ace, and Simpson evenness index). Glomus and Acaulospora were the dominate AMF genera as assessed through their relative abundance and occurrence in control and warming treatments at the different elevations.

Conclusion. The effects of warming on AMF community structure varied depending on elevations. Moreover, the occurrences of AMF in different genera also showed distinct responses to warming in four elevations.

Subjects Biodiversity, Ecology, Ecosystem Science, Mycology, Soil Science Keywords Arbuscular mycorrhizal fungi, Warming, Qinghai-Tibet Plateau, AMF community, AMF richness

\section{INTRODUCTION}

Arbuscular mycorrhizal fungi (AMF) are distributed widely and form symbiotic relationships readily with more than $80 \%$ of vascular plants (Yang et al., 2012; Li et al., 2020; Shi et al., 2020). There are many AMF benefits of the symbiosis to plant physiological, and also broader ecological processes are influenced (Phillips \& Hayman, 1970; Colla, 2008; Ren et al., 2017; Bi, Xiao \& Sun, 2019). AMF utilize carbon in the form of photosynthate from host plants in exchange for enhanced nutrient access to the plant from the symbiosis (Shi et al., 2014). Mycorrhizal plants can also transfer more photosynthate from shoot to roots of non-mycorrhizal plants (Marschner, Crowley \& Higashi, 1997). 
49

50

51

52

53

54

55

56

57

58

59

60

61

62

63

64

65

66

67

68

69

70

71

72

73

74

75

76

77

78

79

AMF are important components of soil biological processes and functional links between plants and soil (Yang et al., 2010). Mycorrhizal fungi have a vital impact on the composition of microbial and plant communities (van der Heijden et al., 2015; Genre, 2020), and AMF symbiosis can also improve nutrient and water supply to host plants (Parniske, 2008; Song et al., 2015; Wang, Pokharel \& Chen, 2019; Sarmiento-López et al., 2020; Shi et al., 2020). Positive plant water relations by AMF have been demonstrated to improve plant drought resistance (Chen et al. 2020) by enhancing the uptake of $\mathrm{N}$ and $\mathrm{P}$ under drought stress (Hashem et al. 2018), alleviate soil water stress (Mickan et al., 2016), and promote plants to deplete soil moisture to alleviate plant water stress (Hardie, 1985). Many studies also suggested that AMF may promote plant growth through enhance tolerance to abiotic stress, such as drought and salinity (Yang et al., 2016; Xiang et al., 2016; McKibben \& Henning, 2018; Higo et al., 2019; Zhang et al., 2019; Zhang et al., 2019; Wu et al., 2021).

Mycorrhizas also play an important role in biodiversity of plants and ecosystem functions (Zhao et al., 2017; He et al., 2010), by influencing plant community diversity and composition (van der Heijden et al., 1998, 2004; Pagano, Cabello \& Scotti, 2010). Therefore, AMF play a fundamental role in the origin, evolution, distribution, survival, growth, and development of plants and larger ecosystem scale processes (Liu \& Wang, 2003; Wang \& Qiu, 2006; Mcguire et al., 2008; Hiiesalu, 2014). AMF has an independent phylum Glomeromycota based on taxonomic status, which probably evolved from Ascomycota and Basidiomycota (Schußler et al., 2001), and has an estimated1250 species of AMF worldwide (Borstler et al., 2006). Opik et al. (2013) analyzed the AMF community of 96 plant roots and found 59 new virtual taxa (VT), using high throughput bar coded amplicon diversity profiling. Overall, the preservation of AMF diversity is important for plant diversity, net primary productivity, and ecosystem maintenance (Mahmoudi et al., 2019).

With the challenges of climate change, and the influence of global warming on AMF community composition has received greater attention due to their role in larger ecosystem level processes (Sun et al., 2013). Under moderate temperature there can be positive influences of AMF plant tolerance to salinity, indicating temperature is a key component to AMF related processes ( $W u \& Z o u, 2010)$. Transferred carbon from host plants to AMF can also be temperature dependent, with reported increases below $18{ }^{\circ} \mathrm{C}$ with warming and decreases above $18^{\circ} \mathrm{C}$ (Gavito et al., 2015). Warming directly decreased AMF colonization across plant species 
80

81

82

83

84

85

86

87

88

89

90

91

92

93

94

95

96

97

98

99

100

101

102

103

104

105

106

107 108

109

and across the climate gradient in prairie plants along a Mediterranean climate gradient (Wilson et al., 2016). Warming has also been demonstrated to reduce AMF species richness, though there were no negative effects (Shi et al., 2017). However, they only studied the influence of warming on AMF in single elevation, which was probably difficult to evaluate accurately the responses of AMF to warming during climate changes.

The most sensitive region to climate changes in the world is the Qinghai-Tibet Plateau (QTP), where is a global biodiversity hotspot because it provides a natural "laboratory" for the development of natural science research with unique geographical environment (Tian et al., 2009; Shi et al., 2015). How AMF communities respond to warming at different elevations is limited on the Qinghai-Tibetan Plateau, and to this end we investigated the influence of warming on AMF community based on four elevations.

1 Due to the temperature-sensitive nature of the Qinghai-Tibet Plateau, we have made the following assumptions: (1) Warming significantly changes the AMF community structure. (2) Warming significantly changes AMF richness. (3) The changes of AMF community are consistent at four elevations after warming.

\section{MATERIALS \& METHODS}

\section{Site Description}

The Qinghai-Tibet Plateau is a vast plateau in Central Asia covering most of the Tibet Autonomous Region and Qinghai Province in China. Referred to as the "the roof of the world" occupying 2.5 million square kilometers, it is the highest and biggest plateau of the world. The annual average temperature is $-4{ }^{\circ} \mathrm{C}$, with annual precipitation ranges from $100 \mathrm{~mm}$ to $300 \mathrm{~mm}$.

In our study, the main vegetation is Kobresia pygmea and the type of soil is alpine meadow soil. The slope for each sampling site is less than $2^{\circ}$. In view of the uniqueness of climatic and topographical characteristics on QTP, this study selected samples between $29^{\circ} 50^{\prime} 36.49^{\prime \prime}$ $29^{\circ} 54^{\prime} 26.70^{\prime \prime}$ north latitude and $102^{\circ} 0^{\prime} 42.50^{\prime \prime}-102^{\circ} 02^{\prime} 9.50^{\prime \prime}$ east longitude on the eastern part of QTP (Table 1).

Table 1. The sampling sites and coordinates based on different elevations on the Qinghai-Tibet Plateau.

Experiment design and sample collection 
110 Quadrats of $20 \mathrm{~m} \times 20 \mathrm{~m}$ were positioned at four elevations of $3000 \mathrm{~m}, 3500 \mathrm{~m}, 3800 \mathrm{~m}$ and $1114170 \mathrm{~m}$ on QTP. Each quadrat was divided into 25 of $4 \mathrm{~m} \times 4 \mathrm{~m}$ little quadrats. We took three 112 biological repetitions with non-adjacent randomly as control treatment (CK) and OTC warming 113 treatment (OTC) by the way of artificial and simulated warming through open-top chamber, 114 respectively (Gao \& Li, 2019; Li et al., 2020). Compared with other warming methods, it can 115 ensure that the soil is basically undamaged and easily to repeated (Klein, Harte \& Zhao, 2004).

116 The top and bottom are hexagonal and open with the side composed of six trapezoid-shaped 117 plexiglass. We carried out a one-year warming test and all samples were taken in August and 118 September of the next year without rain or snow. Small meteorological observation stations were 119 set up at each altitude to monitor soil temperature and moisture. Instantaneous measurement of 120 soil temperature and soil moisture was performed by fixed-point measurement using HOBO 121 PRO temperature and soil moisture recorder. We selected soils samples randomly with a soil 122 corer with diameter of two $\mathrm{cm}$ and depth of $0-20 \mathrm{~cm}$. We mixed three soil cores as a sample and 123 repeated three times in CK and OTC, respectively. Then, separating the root system from the soil 124 and sealing with sterile plastic valve bags, with DNA samples being stored at $-20^{\circ} \mathrm{C}$. Field 125 experiments were approved by the Key Laboratory of Mountain Surface Processes and 126 Ecological Regulation, Chinese Academy of Sciences (20160416).

\section{DNA extraction and PCR amplification}

128 Genomic DNA was extracted from soil samples, using the Fast DNA SPIN Kit for Soil (MP 129 Biomedicals LLC, Santa Ana, CA, USA) according to manufacturer's protocols. The final DNA 130 purification and concentration were determined by Nano Drop 2000 UV-vis spectrophotometer 131 (Thermo Scientific, Wilmington, USA), and DNA quality was checked by 1\% agarose gel 132 electrophoresis. The extracted DNA was subjected to nested PCR by thermocycler PCR system 133 (GeneAmp 9700, ABI, USA). The first PCR amplification was performed with primers AML1F 134 (5'-ATCAACTTTCGATGGTAGGATAGA-3') and AML2R (5'-GAACCCAAACACTTTGGTT 135 TCC-3') by an ABI GeneAmp ${ }^{\circledR} 9700$ PCR thermocycler (ABI, CA, USA) (Lee, Lee \& Young, 136 2008; $L i, 2019)$. The PCR reactions were conducted using the following program: $3 \mathrm{~min}$ of 137 denaturation at $95{ }^{\circ} \mathrm{C}, 32$ cycles of $30 \mathrm{~s}$ at $95^{\circ} \mathrm{C}, 30 \mathrm{~s}$ for annealing at $55^{\circ} \mathrm{C}$, and $45 \mathrm{~s}$ for 138 elongation at $72{ }^{\circ} \mathrm{C}$, and a final extension at $72{ }^{\circ} \mathrm{C}$ for $10 \mathrm{~min}$. PCR reactions were performed in 139 triplicate $20 \mu \mathrm{L}$ mixture containing $4 \mu \mathrm{L}$ of $5 \times$ FastPfu Buffer, $2 \mu \mathrm{L}$ of $2.5 \mathrm{mM}$ dNTPs, $0.8 \mu \mathrm{L}$ 140 of each primer $(5 \mu \mathrm{M}), 0.4 \mu \mathrm{L}$ of FastPfu Polymerase and $10 \mathrm{ng}$ of template DNA. The second 
141 PCR amplication used identical reaction conditions described above with the primers AMDGR 142 (5'-CCCA ACTATCCCTATTAATCAT-3') and AMV4-5NF (5'-AAGCTCGTAGTTGAATTTC 143 G-3') (Shi et al., 2019), and the following program: 3 min of denaturation at $95{ }^{\circ} \mathrm{C}, 30$ cycles of $14430 \mathrm{~s}$ at $95{ }^{\circ} \mathrm{C}, 30 \mathrm{~s}$ for annealing at $55^{\circ} \mathrm{C}$, and $45 \mathrm{~s}$ for elongation at $72{ }^{\circ} \mathrm{C}$, and a final extension 145 at $72{ }^{\circ} \mathrm{C}$ for $10 \mathrm{~min}$. The resulted PCR products were extracted from a $2 \%$ agarose gel and 146 further purified using the Axy.IPrep DNA Gel Extraction Kit (Axygen Biosciences, Union City, 147 CA, USA) and quantified using QuantiFluor ${ }^{\text {TM}}$-ST (Promega, USA) according to the 148 manufacturer's protocol.

\section{Illumina MiSeq DNA sequencing}

150 Purified barcoded amplicons were pooled in equimolar concentrations and paired-end sequenced 151 on an Illumina MiSeq PE300 platform/NovaSeq PE250 platform (Illumina, San Diego, USA) 152 according to the standard protocols by Majorbio Bio-Pharm Technology Co. Ltd. (Shanghai, 153 China). The raw reads were deposited into the NCBI Sequence Read Archive (SRA) database 154 (Accession Number: PRJNA694003 http://www.ncbi.nlm.nih.gov/bioproject/694003).

\section{Processing of sequencing data}

156 The raw sequencing reads were demultiplexed, quality-filtered by fastp version 0.20.0 (Chen et 157 al., 2018) and merged by FLASH version 1.2.7(Magoč and Salzberg, 2011). Microbial 158 community sequencing was conducted by Shanghai Majorbio Bio-pharm Technology using 159 Illumina-MiSeq sequencing platform. The data were analyzed on a free online platform 160 (Majorbio I-Sanger Cloud Platform, www.i-sanger.com).

Operational taxonomic units (OTUs) were clustered with 97\% similarity cutoff using 162 UPARSE version 7.1, and chimeric sequences were identified and removed (Stackebrandt and Goebel, 1994; Edgar et al., 2013). The taxonomy of each OTU representative sequence was analyzed by RDP Classifier version 2.2 against the maarjam081/AM database using confidence threshold of 70\% (Wang et al., 2007).

The raw sequence data were deposited at NCBI, in the SRA database with the following 167 accession: PRJNA694003 (http://www.ncbi.nlm.nih.gov/bioproject/694003).

\section{Data Analysis}

Total soil carbon, nitrogen, and sulphur were determined by an elemental analyser (GC 
172 At the same time, we found that the soil temperature was increased $1.4{ }^{\circ} \mathrm{C}$. The dynamic range of

173 the soil temperature was increased from $0.6^{\circ} \mathrm{C}$ to $2.4{ }^{\circ} \mathrm{C}$ in different elevations. The soil

174 moisture decreased $0.07 \mathrm{~m}^{3}$. The soil moisture increased $0.15 \mathrm{~m}^{3}$ at $4170 \mathrm{~m}$ and decreased 0.11

$175 \mathrm{~m}^{3}, 0.09 \mathrm{~m}^{3}$, and $0.25 \mathrm{~m}^{3}$ at $3000 \mathrm{~m}, 3500 \mathrm{~m}$, and $3800 \mathrm{~m}$.

176 The community was expressed by AMF richness, relative abundance and occurrence

177 frequency in different elevations. AMF richness was calculated by the number of OTUs. The

178 relative abundance of AM fungal genus was calculated as the percentage of the sequence number

179 of OTUs in each genus divided by the total sequence number of OTUs in all genera at this

180 altitude. The occurrence frequency of AM fungal genus was defined as the percentage of the

181 number of samples where this genus observed to the number of all samples in this genus. The

182 rate of decrease $=($ the number of OTUs in CK - the number of OTUs in OTC)/ the number of

183 OTUs in $\mathrm{CK} * 100 \%$. The rate of increase $=($ the number of OTUs in OTC - the number of OTUs

184 in CK)/ the number of OTUs in CK * 100\%.

185 AMF alpha diversity in different elevations were expressed and plotted by the index of

186 Shannon, Ace, and Simpson evenness at the level of OTU by SPASS, Excel and Origin,

187 respectively. The differences of AMF richness and AMF diversity in different elevations were

188 analyzed by two-way ANOVA analysis and Duncan in SPSS 19.0 (Shi et al., 2019). We analyze

189 the impact of environmental factors on AMF community after warming through RDA analysis

190 on the website of Majorbio (http:// www.i-sanger.com). We standardize the data by flattening

191 according to the minimum number of sample sequences on the website of Majorbio (http://

192 www.i-sanger.com). The data of the percentage of relative abundance and occurrence frequency

193 were subjected to square root transformation before analysing and comparing (Shi et al. 2007).

194 RESULTS

195 AMF richness at the level of OTU

196 Warming increased AMF richness at the level of OTU from 36 to 45.67 with the increase of

$19726.86 \%$, among them, AMF richness of shared was 28 OTUs, which was $77.78 \%$ and $61.19 \%$ in

198 CK and OTC, respectively (Figure 1). In CK, there were 8 unique OTUs, which was $22.22 \%$ of

199 the total in CK. AMF richness of shared was 3.5 times to CK solely. In OTC, there were 17.67

200 unique OTUs, which was $38.69 \%$ of the total in OTC. AMF richness was 1.58 times to AMF 
201 richness in OTC solely. AMF richness increased but has no significant effects after warming by 202 two-way ANOVA analysis $(P=0.052)$.

203

204

205

206

207

208

209

210

211

212

213

214

215

216

217

218

219

220

221

222

223

224

225

226

227

228

229

230

231

232

233

234

235

236

Figure 1. The influence of warming on AMF richness. CK means the treatment of control and OTC means the treatment of warming by open-top chamber. Shared means the treatment of CK and OTC in share. The similarity level was $97 \%$. The data were statistically analyzed by ANOVA (warming: $\mathrm{F}=7.509, P=0.052$ ).

\section{AMF diversity indices at the level of OTU based on different elevations}

There were dynamic influences of warming on AMF OTU richness with elevations. OTU richness displayed an upward trend at $3000 \mathrm{~m}, 3500 \mathrm{~m}$ and $3800 \mathrm{~m}$ but then decreased at $4170 \mathrm{~m}$ after warming (Figure 2A). The highest AMF richness occurred at $3500 \mathrm{~m}$ and AMF OTU richness in OTC is greater than that in CK at the elevations of $3000 \mathrm{~m}, 3500 \mathrm{~m}$, and $3800 \mathrm{~m}$, but it was opposite at $4170 \mathrm{~m}$. That was, AMF richness was lower at the higher altitude after warming. Moreover, elevation had extremely significant effects on AMF richness, which increased significantly at $3500 \mathrm{~m}\left(P<0.001^{* *}\right)$. The interaction of elevations and warming also had a significant effect on AMF richness $\left(P=0.029^{*}\right)$. The Shannon index has the same tendency to AMF richness (Figure 2B). At $3000 \mathrm{~m}, 3500 \mathrm{~m}$, and $3800 \mathrm{~m}$, the Shannon index in OTC were higher than that in $\mathrm{CK}$, but showed an opposite trend at $4170 \mathrm{~m}$ and none of them are significant. The Simpson evenness index had a similar trend to the Shannon index at $3000 \mathrm{~m}$ (Figure 2C).

At $3000 \mathrm{~m}$ and $3500 \mathrm{~m}$, the Ace diversity index in OTC were higher than that in CK, but it was opposite at $3800 \mathrm{~m}$ and $4170 \mathrm{~m}$ (Figure 2D). Elevation had significant effects on the Ace index $\left(P=0.045^{*}\right)$.

Figure 2. AMF diversity index at the level of OTU based on different elevations were statistically analyzed through ANOVA by warming. Error bars represent the standard error of the mean. Different lowercase letters above each column indicate significant difference, $P<0.05$. The data were statistically analyzed by ANOVA (elevations: $\mathrm{F}=15.387, P=0.001 * *$; warming: $\mathrm{F}=1.347, P=0.263$; elevations $\times$ warming: $\mathrm{F}=3.874, P=0.029^{*}$ ), Shannon index (elevations: $\mathrm{F}=2.805, P=0.073$; warming: $\mathrm{F}=0.682, P=0.421$; elevations $\times$ warming: $\mathrm{F}=2.358, P$ $=0.110$ ), Simpson evenness index (elevations: $\mathrm{F}=0.768, P=0.529$; warming: $\mathrm{F}=0.471, P=0.502$; elevations $\times$ warming: $\mathrm{F}=1.594, P=0.230$ ), Ace index (elevations: $\mathrm{F}=3.369, P=0.045^{*}$; warming: $\mathrm{F}=0.047, P=$ 0.832; elevations $\times$ warming: $\mathrm{F}=1.578, P=0.234$ ).

\section{The influence of warming on AMF community based on different elevations}

Among the genera of Ambispora, Unclassified (Archaeosporales order), and Paraglomus, AMF richness of CK was identical with OTC (Table 2). The largest change in AMF richness was

Peer] reviewing PDF | (2021:01:57095:2:1:NEW 17 Jun 2021) 
237 Glomus, which increased from 13.67 to 20.33 after warming. For Acaulospora, AMF richness 238 was increased from 10.67 OTUs to 12.33 OTUs. The smallest change in AMF richness was 239 Archaeospora, which increased from 4 to 4.33.

240 In addition, there was a downward trend at $4170 \mathrm{~m}$ and the decline rate was $100 \%$. However, 241 there was an increasing trend at $3500 \mathrm{~m}$ and $3800 \mathrm{~m}$. For Archaeospora, AMF richness was 242 increased at $3800 \mathrm{~m}$, but decreased at $3500 \mathrm{~m}$ and $4170 \mathrm{~m}$. For Acaulospora, AMF richness 243 trended to increase $7.28 \%$ and $26.38 \%$ at $3000 \mathrm{~m}$ and $3500 \mathrm{~m}$, respectively. As for $4170 \mathrm{~m}$, it 244 decreased $42.86 \%$. For Glomus, AMF richness was increased $116.5 \%, 58.53 \%$, and $38.83 \%$ at $2453000 \mathrm{~m}, 3500 \mathrm{~m}$, and $3800 \mathrm{~m}$, respectively, and then decreased at $4170 \mathrm{~m}$., AMF richness of 246 Paraglomus increased at $3000 \mathrm{~m}$ and decreased at $4170 \mathrm{~m}$. Moreover, the rate of increase on 247 AMF richness at $3000 \mathrm{~m}$ was the same as the rate of decrease at $4170 \mathrm{~m}$.

248

249

250

251

252

253

254

255

256

257

258

259

260

261

262

263

264

265

266

267

268

269

270

271

\section{Table 2. The influence of warming on AMF richness based on different elevations.}

Notes:

CK means the treatment of control and OTC means the treatment of warming by open-top chamber. Shared means the treatment of CK and OTC in share.

The beta-diversity of the AMF community was determined by the Bray-Curtis method (Figure 3). In the 2-dimensional NMDS plots, soil samples collected from the four different elevations and the two different treatment separated from each other indicating a divergence of the warming treatment. To test the significance an ANOSIM based on the Bray-Curtis distance showed dissimilarities of the AMF community at the OTU level among the four different elevations and two different treatments $(P=0.001)$.

Figure 3. Nonmetric multidimensional scaling (NMDS) of the influence of warming on AMF community at the level of OTU. The symbols represent the elevations of $3000 \mathrm{~m}, 3500 \mathrm{~m}, 3800 \mathrm{~m}$, and 4170m. CK means the treatment of control and OTC means the treatment of warming by open-top chamber.

\section{The relative abundance and occurrence frequency of AMF}

For four different elevations, the relative abundance of Acaulospora and Glomus were the largest before and after warming (Table 3). The relative abundance of Acaulospora and Glomus were opposite in four different elevations. At $3000 \mathrm{~m}$, the relative abundance of other genera showed an increasing trend after warming, except Glomus was decreased from $79 \%$ to $65 \%$. At $3500 \mathrm{~m}$, the relative abundance of Ambispora and Glomus showed an increasing trend after warming, but Archaeospora and Acaulospora decreased. At $3800 \mathrm{~m}$, the relative abundance of Glomus showed

Peer) reviewing PDF | (2021:01:57095:2:1:NEW 17 Jun 2021) 
272 an increasing trend but the relative abundance of Ambispora, Archaeospora, and Acaulospora

273 showed a decreasing trend after warming. As for $4170 \mathrm{~m}$, the relative abundance of

274 Archaeospora and Acaulospora increased but Ambispora, Glomus and Paraglomus decreased.

275 The relative abundance of Glomus decreased at $3000 \mathrm{~m}$ and $4170 \mathrm{~m}$, but Acaulospora increased 276 after warming.

277

278

279

280

281

282

283

284

285

286

287

288

289

290

291

292

293

294

295

296

297

298

299

300

301

Table 3. The influence of warming on the relative abundance of AMF based on different elevations.

Notes:

CK means the treatment of control and OTC means the treatment of warming by open-top chamber. Shared means the treatment of CK and OTC in share.

For the four different elevations, Acaulospora was always present (Table 4), as was the occurrence of Glomus, except at $4170 \mathrm{~m}$ in the OTC treatment. In CK, the occurrence frequency of Acaulospora was the same as that in OTC at different elevations, which seemed that warming had no affect on them. The occurrence frequency of Ambispora and Archaeospora varied at three elevations, Paraglomus varied at two elevations and Glomus varied at only one elevations. For different elevations, the occurrence frequency of Paraglomus showed a tendency of increasing from 0 to $33.33 \%$ at $3000 \mathrm{~m}$ but opposite at $4170 \mathrm{~m}$. The occurrence frequency of Ambispora and Archaeospora decreased at $4170 \mathrm{~m}$. But at $3500 \mathrm{~m}$, the tendency of Ambispora and Archaeospora were opposite.

Table 4. The influence of warming on the occurrence frequency of AMF based on different elevations. Notes:

CK means the treatment of control and OTC means the treatment of warming by open-top chamber. Shared means the treatment of CK and OTC in share.

\section{The influence of soil factors on AMF community by warming}

For the four different elevations, RDA1 explained $59.16 \%, 69.55 \%, 95.26 \%$, and $95.35 \%$ at $3000 \mathrm{~m}, 3500 \mathrm{~m}, 3800 \mathrm{~m}$, and $4170 \mathrm{~m}$ of the community structure, respectively. RDA2 explained $0.91 \%, 2.34 \%, 1.52 \%$, and $0.56 \%$ at $3000 \mathrm{~m}, 3500 \mathrm{~m}, 3800 \mathrm{~m}$, and $4170 \mathrm{~m}$, respectively (Figure 302 4A - 4D). RDA1 increased from $59.16 \%$ to $95.35 \%$ with the elevation increased. As the

303 elevations increased, the influence of $\mathrm{C}, \mathrm{N}, \mathrm{S}$, and $\mathrm{C} / \mathrm{N}$ were different. $\mathrm{C}, \mathrm{N}$, and $\mathrm{C} / \mathrm{N}$ were positively correlated to RDA1 and RDA2. Sulfur (S) was negatively correlated to RDA1 but 305 positively correlated to RDA2 at $3000 \mathrm{~m}$ (Figure 4A). At $3500 \mathrm{~m}, \mathrm{C}, \mathrm{N}$, and S were all positively 306 correlated to RDA2 but negatively correlated to RDA1 (Figure 4B). C/N was negatively 
307 correlated to RDA2 but positively correlated to RDA1. C and N were negatively correlated to

$308 \mathrm{RDA} 1$ and RDA2. S and C/N were negatively correlated to RDA2 but positively correlated to $309 \mathrm{RDA} 1$ at $3800 \mathrm{~m}$ (Figure 4C). At $4170 \mathrm{~m}, \mathrm{C}, \mathrm{N}$, and S were negatively correlated to RDA1 and $310 \mathrm{RDA} 2$. C/N was negatively correlated to RDA2 but positively correlated to RDA1 (Figure 4D).

311

312

313

314

315

316

317

318

319

320

321

322

323

324

325

326

327

328

329

330

331

332

333

334

335

336

337

338

339

Figure 4. The influence of warming on RDA analysis at the level of genus based on different elevations. CK means the treatment of control and OTC means the treatment of warming by open-top chamber. A, B, C, and D represent the RDA analysis at $3000 \mathrm{~m}, 3500 \mathrm{~m}, 3800 \mathrm{~m}$, and $4170 \mathrm{~m}$, respectively.

\section{DISCUSSION}

The influence of global warming on AMF community structure and the relationship with plant productivity and diversity are important due to the climate change (Sun et al., 2013; Buscher, 2012). Previous studies investigating the influence of warming on AMF usually occurred at a single elevation, which can't accurately reflect the change of AMF community in mountain areas with broad ecosystem topography (Gai et al., 2012). We investigated the influence of warming on AMF community composition at four different elevations by the way of in-situ through opentop chamber on the Qinghai-Tibet Plateau. Our research showed that warming changed the AMF community were dynamic, and varied depending on elevations.

There was also evidence that warming had no effects on AMF community in the semiarid steppe ecosystem (Gao et al., 2016). This might be due to AMF communities having little sensitivity to short-term climate change (Jiang et al., 2018), or that soil warming had little influence on AMF community were commonly used to seasonal temperature dynamics (Heinemeyer et al., 2003). To complicate the matter, AMF community composition can also be influenced by plant community (Millar \&Bennett, 2016). In our study, we demonstrated that warming increased AMF richness because there were 17 new OTUs were observed in OTC treatment. Interestingly, as the elevations increased with increasing AMF richness from $3000 \mathrm{~m}$ to $3800 \mathrm{~m}$, but then decreased at $4170 \mathrm{~m}$. AMF richness was higher at the elevation $3500 \mathrm{~m}$ but not at other elevations. Meanwhile, our results was also similar to Liu et al. (2016), who suggested that warming does not always lead to significant changes in fungal community composition. We reported warming might not influence AMF community compositions at all elevations in this region and had an upper limit then a decline in species richness. This AMF community composition response was likely related to the soil moisture and temperature as the soil moisture change was the smallest at $3500 \mathrm{~m}$ whether in CK or in OTC and the soil

Peer) reviewing PDF | (2021:01:57095:2:1:NEW 17 Jun 2021) 
340 temperature changed the smallest except $4170 \mathrm{~m}$ (Gai et al., 2009). Sun et al. (2013) demostrated

341 that soil moisture had an influence on AMF community composition. In addition, there could be

342 an inflection point between $3800 \mathrm{~m}$ and $4170 \mathrm{~m}$, which needs further research.

343 The analysis of AMF diversity indices including Shannon index, Ace index, and Simpson

344 evenness index in different elevations found that warming had no significant effects on AMF

345 diversity, which had been reported previously (Gai et al., 2012; Yang et al., 2013; Geml et al.,

346 2015). However, the influences of warming on AMF diversity might be varied in different

347 ecosystems (Kim et al., 2014). Therefore, we argued that overall (at all elevations) warming had

348 little influence on AMF diversity, which might be related to the ecosystems at different

349 elevations. Indeed, it could be that plant species and elevation exert significant influences on

350 AMF diversity (Li et al., 2014), as diversity of the host plants could determine AMF diversity

351 (Shi et al., 2014). Therefore, we suggested that the reason of AMF diversity did not increase

352 could be that plant identity had played an overriding role.

353 Previous studies have shown that there were dominant genera in AMF communities, such as

354 Glomus and Acaulospora (Dobo et al., 2016; Belay, Vestberg \& Assefa, 2013). Our study found

355 that the relative abundance and occurrence frequency of Glomus and Acaulospora were higher

356 whether in CK or OTC than other genera except the occurrence frequency of Glomus at $4170 \mathrm{~m}$,

357 which had been reported before (Sturmer \& Siqueira, 2011; Coutinho et al., 2015). Glomus had

358 been reported to be dominant in roots according to DNA sequencing, though diversity indices

359 did change between sampling roots, hyphae and soil (Mickan et al., 2017). The changes of the

360 relative abundance of Glomus and Acaulospora were just opposite after warming. The relative

361 abundance of Acaulosporaceae had been shown to increase with elevations increased (Yang et

362 al., 2016), which were the same as our study of the relative abundance of Acaulospora

363 (Acaulosporaceae Family) at $3000 \mathrm{~m}$ and $4170 \mathrm{~m}$. It appeared that this genus was differed in

364 adaptability at different elevations after warming and there were also differences between

365 different genera. Besides, studies had also reported that Glomus and Acaulospora were most in

366 different plants, respectively (Schenck \& Kinloch, 1980; Blaszkowski, 1989). Therefore, it

367 indicated that Glomus and Acaulospora were also highly adaptable to different plants in

368 mountainous areas.

369 The influence of warming on RDA analysis showed that RDA1 increased with elevation

370 increased. At the same time, $\mathrm{C}$ and $\mathrm{N}$ were from positively correlated to RDA1 and RDA2 at

Peer] reviewing PDF | (2021:01:57095:2:1:NEW 17 Jun 2021) 
$3713000 \mathrm{~m}$ to be negatively correlated to RDA1 and RDA2 at $3800 \mathrm{~m}$ and $4170 \mathrm{~m}$. C/N had a great 372 effect at $3000 \mathrm{~m}, 3500 \mathrm{~m}$, and $3800 \mathrm{~m}$, but opposite at $4170 \mathrm{~m}$. And the influence of C, N, and S 373 were greater at $4170 \mathrm{~m}$ than that of other three elevations. It indicated that soil factors might 374 change the direction of action on AMF community, though none of them were significant in this 375 experiment.

376

377

378

379

380

381

382

383

384

385

386

387

388

389

390

391

392

393

394

395

396

397

398

399

400

401

402

403

404

\section{Conclusions}

Warming changed the AMF community were dynamic, and these responses varied depending on elevations which consistent with our assumptions that warming significantly changed AMF community structure. Moreover, the occurrences of AMF in different genera also presented the different responses to warming in four elevations. Our results imply that climate change effect of global warming and geographical elevation lead to changes in AMF community, which play an important role in the responses of ecosystem level processes.

\section{Acknowledgements}

This research was funded by NSFC (31670499), Program for Science \& Technology Innovation Talents in Universities of Henan Province (18HASTIT013), Scientific and technological research projects in Henan province (192102110128), Key Laboratory of Mountain Surface Processes and Ecological Regulation, CAS (20160618), Training Program for college students (202010464067, 2020337), the Innovation Team Foundation (2015TTD002) of Henan University of Science \& Technology.

\section{References}

Belay Z, Vestberg M, Assefa F. 2013. Diversity and abundance of arbuscular mycorrhizal fungi associated with acacia trees from different land use systems in Ethiopia. African Journal of Microbiology Research 7: 5503-5515 DOI 10.5897/AJMR2013.6115.

Bi YL, Xiao L, Sun JH. 2019. An arbuscular mycorrhizal fungus ameliorates plant growth and hormones after moderate root damage due to simulated coal mining subsidence: a microcosm study. Environmental Science and Pollution Research 26: 11053-11061 DOI 10.1007/s11356019-04559-7.

Blaszkowski J. 1989. The occurrence of the Endogonaceae in Poland. Agriculture Ecosystems and Environment 29: 45-50 DOI 10.1016/0167-8809(90)90252-9.

Borstler B, Renker C, Kahmen A, Buscot F. 2006. Species composition of arbuscular mycorrhizal fungi in two mountain meadows with differing management types and levels of plant biodiversity. Biology and Fertility of Soils 42: 286-298 DOI 10.1007/s00374-005-0026-9. Buscher M, Zavalloni C, de Boulois HD, Vicca S, Van den Berge J, Declerck S, Ceulemans R, Janssens IA, Nijs I. 2012. Effects of arbuscular mycorrhizal fungi on grassland productivity 
405 are altered by future climate and below-ground resource availability. Environmental and

406 Experimental Botany 81: 62-71 DOI 10.1016/j.envexpbot.2012.03.003.

407 Chen S, Zhou Y, Chen Y, Gu J. 2018. Fastp: an ultra-fast all-in-one FASTQ preprocessor.

408 Bioinformatics 34: i884-i890. DOI 10.1093/bioinformatics/bty560.

409 Chen W, Meng PP, Feng H, Wang CY. 2020. Effects of Arbuscular Mycorrhizal Fungi on

410 Growth and Physiological Performance of Catalpa bungei C.A.Mey. Under Drought Stress.

411 Forests 11: 1117 DOI 10.3390/f11101117.

412 Colla G, Rouphael Y, Cardarelli M, Tullio M, Rivera CM, Rea E. 2008. Alleviation of salt

413 stress by arbuscular mycorrhizal in zucchini plants grown at low and high phosphorus

414 concentration. Biology and Fertility of Soils 44: 501-509 DOI 10.1007/s00374-007-0232-8.

415 Coutinho ES, Fernandes GW, Berbara RLL, Valerio HM, Goto BT. 2015. Variation of

416 arbuscular mycorrhizal fungal communities along an altitudinal gradient in rupestrian grasslands

417 in Brazil. Mycorrhiza 25: 627-638 DOI 10.1007/s00572-015-0636-5.

418 Dobo B, Asefa F, Asfaw Z. 2016. Diversity and abundance of arbuscular mycorrhizal fungi

419 under different plant and soil properties in Sidama, Southern Ethiopia. Agroforestry Systems 92 :

420 91-101 DOI 10.1007/s10457-016-0017-x.

421 Edgar RC. 2013. UPARSE: highly accurate OTU sequences from microbial amplicon reads.

422 Nat Methods 10: 996-998. DOI 10.1038/nmeth.2604.

423 Gai JP, Christie P, Cai XB, Fan JQ, Zhang JL, Feng G, Li XL. 2009. Occurrence and

424 distribution of arbuscular mycorrhizal fungal species in three types of grassland community of

425 the Tibetan Plateau. Ecological Research 24: 1345-1350 DOI 10.1007/s11284-009-0618-1.

426 Gai JP, Tian H, Yang FY, Christie P, Li XL, Klironomos JN. 2012. Arbuscular mycorrhizal

427 fungal diversity along a Tibetan elevation gradient. Pedobiologia (Jena) 55: 145-151 DOI

428 10.1016/j.pedobi.2011.12.004.

429 Gao C, Kim YC, Zheng Y, Yang W, Chen L, Ji NN, Wan SQ, Guo LD. 2016. Increased

430 precipitation, rather than warming, exerts a strong influence on arbuscular mycorrhizal fungal

431 community in a semiarid steppe ecosystem. Botany 94: 459-469 DOI info:doi/10.1139/cjb-2015-

4320210.

433 Gao LL, Li FD. 2019. Effect of Simulated Temperature Enhancement on Wheat Growth, Soil

434 Enzyme Activity and Respiration. Research of Soil and Water Conservation 26: 359-363, 371

435 DOI 10.13869/j.cnki.rswc.2019.06.048.

436 Gavito ME, Olsson PA, Rouhier H, Medina-Penafied A, Jakobsen I, Bago A, Azcon-

437 Geml J, Morgado LN, Semenova TA, Welker JM, Walker MD, Smets E. 2015. Long-term

438 warming alters richness and composition of taxonomic and functional groups of arctic fungi.

439 FEMS Microbiology Ecology 8: 8 DOI 10.1093/femsec/fiv095.

440 Genre A, Lanfranco L, Perotto S, Bonfante P. 2020. Unique and common traits in

441 mycorrhizal symbioses. Nature Reviews Microbiology 18: 649-660 DOI 10.1038/s41579-020-

442 0402-3.

443 Hardie K. 1985. The effect of removal of extraradical hyphae on water-uptake by vesicular

444 arbuscular mycorrhizal plants. New Phytologist 101: 677-684 DOI 10.2307/2432901. 
445 Hashem A, Kumar A, Al-Dbass AM, Alqarawi AA, Al-Arjani ABF, Singh G, Farooq M, 446 Abd_Allah EF. 2018. Arbuscular mycorrhizal fungi and biochar improves drought tolerance in 447 chickpea. Saudi Journal of Biological Sciences 26: 614-624 DOI 10.1016/j.sjbs.2018.11.005.

448 He XH, Duan YH, Chen YL, Xu MG. 2010. A 60-year journey of mycorrhizal research in 449 China: Past, present and future directions. Science China-Life Sciences 53: 1374-1398 DOI 450 10.1007/s11427-010-4096-z.

451 Heinemeyer A, Ridgway KP, Edwards EJ, Benham DG, Young J P, Fitter AH. 2003.

452 Impact of soil warming and shading on colonization and community structure of arbuscular 453 mycorrhizal fungi in roots of a native grassland community. Global Change Biology 10: 52-64 454 DOI 10.1046/j.1529-8817.2003.00713.x.

455 Higo M, Tatewaki YY, Gunji K, Kaseda A, Isobe K. 2019. Cover cropping can be a stronger 456 determinant than host crop identity for arbuscular mycorrhizal fungal communities colonizing 457 maize and soybean. PeerJ 7: e6403 DOI 10.7717/peerj.6403.

458 Hiiesalu I, Partel M, Davison J, Gerhold P, Metsis M, Moora M, Opik M, Vasar M, Zobel 459 M, Wilson SD. 2014. Species richness of arbuscular mycorrhizal fungi: associations with 460 grassland plant richness and biomass. New Phytologist 203: 233-244 DOI 10.1111/nph.12765.

461 Jiang SJ, Pan JB, Shi GX, Dorji T, Hopping KA, Klein AJ, Liu YJ, Feng HY. 2018. 462 Identification of root-colonizing AM fungal communities and their responses to short-term 463 climate change and grazing on Tibetan plateau. Symbiosis 74: 159-166 DOI 10.1007/s13199464 017-0497-0.

465 Kim YC, Gao C, Zheng Y, Yang W, Chen L, He XH, Wan SQ, Guo LD. 2014. Different 466 responses of arbuscular mycorrhizal fungal community to day-time and night-time warming in a 467 semiarid steppe. Chinese Sci Bull 59: 5080-5089 DOI 10.1007/s11434-014-0602-1.

468 Klein JA, Harte J, Zhao XQ. 2004. Experimental warming causes large and rapid species loss, 469 dampened by simulated grazing, on the Tibetan Plateau. Ecology Letters 7: 1170-1179 DOI $47010.1111 /$ j.1461-0248.2004.00677.x.

471 Lee J, Lee S, Young JPW. 2008. Improved PCR primers for the detection and identification of 472 arbuscular mycorrhizal fungi. FEMS microbiology ecology 65: 339-349 DOI 10.1111/j.1574473 6941.2008.00531.x.

474 Li L, McCormack ML, Chen FS, Wang HM, Ma ZQ, Guo DL. 2019. Different responses of 475 absorptive roots and arbuscular mycorrhizal fungi to fertilization provide diverse nutrient 476 acquisition strategies in Chinese fir. Forest Ecology and Management 433: 64-72 DOI 477 10.1016/j.foreco.2018.10.055.

478 Li XL, Gai JP, Cai XB, Li XL, Christie P, Zhang FS, Zhang JL. 2014. Molecular diversity of 479 arbuscular mycorrhizal fungi associated with two co-occurring perennial plant species on a 480 Tibetan altitudinal gradient. Mycorrhiza 24: 95-107 DOI 10.1007/s00572-013-0518-7.

481 Li XL, Xu MH, Meng WZ, Liu Q, Liu M. 2020. Effects of experimental warming on the 482 hydrothermic factor and community structure of subalpine meadow on Yunding Mountain, 483 Shanxi Province, China. Acta Ecologica Sinica 40: 6885-6896 DOI 10.5846/stxb201907291600. 
484 Li ZF, Lü PP, Wang YL, Yao H, Maitra P, Sun X, Zheng Y, Guo LD. 2020. Response of 485 arbuscular mycorrhizal fungal community in soil and roots to grazing differs in a wetland on the 486 Qinghai-Tibet plateau. PeerJ 8: e9375 DOI 10.7717/peerj.9375.

487 Liu RJ, Wang FY. 2003. Selection of appropriate host plants used in trap culture of arbuscular 488 mycorrhizal fungi. Mycorrhiza 13: 123-127 DOI 10.1007/s00572-002-0207-4.

489 Liu Y, Zhang H, Xiong MH, Li F, Li LQ, Wang GL, Pan GX. 2016. Abundance and 490 composition response of wheat field soil bacterial and fungal communities to elevated CO2 and 491 increased air temperature. Biology and Fertility of Soils 53: 3-8 DOI 10.1007/s00374-016-11594928.

493 Magoč T, Salzberg SL. 2011. FLASH: fast length adjustment of short reads to improve genome 494 assemblies. Bioinformatics 27: 2957-2963. DOI 10.1093/bioinformatics/btr507.

496

497

Mahmoudi N, Cruz C, Mahdhi M, Mars M, Caeiro MF. 2019. Arbuscular mycorrhizal fungi in soil, roots and rhizosphere of Medicago truncatula: diversity and heterogeneity under semiarid conditions. PeerJ 7: e6401 DOI 10.7717/peerj.6401.

498 Marschner P, Crowley DE, Higashi RM. 1997. Root exudation and physiological status of a root-colonizing fluorescent pseudomonad in mycorrhizal and non-mycorrhizal pepper (Capsicum

500 annuum L.). Plant and Soil 189: 11-20 DOI 10.1023/A: 1004266907442.

501 Mcguire KL, Henkel TW, Cerda IGDL, Villa G, Edmund F, Andrew C. 2008. Dual 502 mycorrhizal colonization of forest-dominating tropical trees and the mycorrhizal status of non503 dominant tree and liana species. Mycorrhiza 18: 217-222 DOI 10.1007/s00572-008-0170-9.

504 Mckibben M, Henning JA. 2018. Hemiparasitic plants increase alpine plant richness and 505 evenness but reduce arbuscular mycorrhizal fungal colonization in dominant plant species. PeerJ 506 6: e5682 DOI 10.7717/peerj.5682.

507 Mickan BS, Abbott LK, Stefanova K, Solaiman ZM. 2016. Interactions between biochar and 508 mycorrhizal fungi in a water-stressed agricultural soil. Mycorrhiza 26: 565-574 DOI 509 10.1007/s00572-016-0693-4.

510 Mickan BS, Hart MM, Solaiman ZM, Jenkins S, Siddique KHM, Abbott LK. 2017.

511 Molecular divergence of fungal communities in soil, roots and hyphae highlight the importance 512 of sampling strategies. Rhizosphere 4: 104-111 DOI 10.1016/j.rhisph.2017.09.003.

513 Millar NS, Bennett AE. 2016. Stressed out symbiotes: hypotheses for the influence of abiotic 514 stress on arbuscular mycorrhizal fungi. Oecologia 182: 625-641 DOI 10.1007/s00442-016-36735157.

516 Opik M, Zobel M, Cantero JJ, Davison J, Facelli JM, Hiiesalu I, Jairus T, Kalwij JM, 517 Koorem K, Leal ME, Liira J, Metsis M, Neshataeva V, Paal J, Phosri C, Polme S, Reier U, 518 Saks U, Schimann H, Thiery O, Vasar M, Moora M. 2013. Global sampling of plant roots 519 expands the described molecular diversity of arbuscular mycorrhizal fungi. Mycorrhiza 23: 411520430 DOI 10.1007/s00572-013-0482-2.

521 Pagano MC, Cabello MN, Scotti MR. 2010. Arbuscular mycorrhizal colonization and growth 522 of Eremanthus incanus Less. in a highland field. Plant, Soil and Environment 56: 412-418 DOI 523 10.17221/104/2009-PSE. 
524 Parniske M. 2008. Arbuscular mycorrhiza: the mother of plant root endosymbioses. Nature

525

526

527

528

529

530

531

532

533

534

535

536

537

538

539

540

541

542

543

544

545

546

547

548

549

550

551

552

553

554

555

556

557

558

559

560

561

562

563

Reviews Microbiology 6: 763-775 DOI 10.1038/nrmicro1987.

Phillips JM, Hayman DS. 1970. Improved procedures for clearing roots and staining parasitic and vesicular-arbuscular mycorrhizal fungi for rapid assement of infection. Transactions of the British Mycological Society 55: 158-161 DOI 10.1016/S0007-1536(70)80110-3.

Ren HY, Gao T, Hu J, Yang GW. 2017. The effects of arbuscular mycorrhizal fungi and root interaction on the competition between Trifolium repens and Lolium perenne. PeerJ 5: e4183 DOI 10.7717/peerj.4183.

\section{Sarmiento-López LG, López-Meyer M, Sepúlveda-Jiménez G, Cárdenas L, Rodríguez-}

Monroy M. 2020. Photosynthetic performance and stevioside concentration are improved by the arbuscular mycorrhizal symbiosis in Stevia rebaudiana under different phosphate concentrations. PeerJ 8: e10173 DOI 10.7717/peerj.10173.

Schenck NC, Kinloch RA. 1980. Incidence of mycorrhizal fungi on six fieldcrops in monoculture on a newly cleared woodland site. Mycologia 72: 445-456 DOI 10.2307/3759518.

Schußler A, Schwarzott D, Walker C. 2001. A new fungal phylum, the Glomeromycota: phylogeny and evolution. Mycological Research 105: 1413-1421 DOI 10.1017/S0953756201005196.

Shi GX, Yao BQ, Liu YJ, Jiang SJ, Wang WY, Pan JB, Zhao XQ, Feng HY, Zhou HK. 2017. The phylogenetic structure of AMF communities shifts in response to gradient warming with and without winter grazing on the Qinghai-Tibet Plateau. APPLIED SOIL ECOLOGY 121: 31-40 DOI: 10.1016/j.apsoil.2017.09.010.

Shi ZY, Li K, Zhu XY, Wang FY. 2020. The worldwide leaf economic spectrum traits are closely linked with mycorrhizal traits. Fungal Ecology 43: 100877 DOI 10.1016/j.funeco.2019.100877.

Shi ZY, Miao YF, Wang FY. 2014. Forest soil autotrophic and heterotrophic respiration under different mycorrhizal strategies and their responses to temperature and precipitation. Contemporary Problems of Ecology 7: 32-38 DOI 10.1134/S1995425514010120.

Shi ZY, Wang FY, Zhang K, Chen YL. 2014. Diversity and distribution of arbuscular mycorrhizal fungi along altitudinal gradients in Mount Taibai of the Qinling Mountains. Canadian Journal of Microbiology 60: 811-818 DOI 10.1139/cjm-2014-0416.

Shi ZY, Yin KJ, Wang FY, Mickan BS, Wang XG, Zhou WL, Li YJ. 2019. Alterations of Arbuscular Mycorrhizal Fungal Diversity in Soil with Elevation in Tropical Forests of China. Diversity 11: 181-190 DOI 10.3390/d11100181.

Shi ZY, Yin XB, Mickan B, Wang FY, Zhang Y, Li YN, Shen HH. 2015. Response of Arbuscular Mycorrhizal Fungi to Simulated Climate Changes by Reciprocal Translocation in Tibetan Plateau. Notulae Botanicae Horti Agrobotanici Cluj-Napocan 43: 488-493 DOI 10.15835/nbha4329946.

Shi ZY, Zhang JC, Lu SC, Li Y, Wang FY. 2020. Arbuscular Mycorrhizal Fungi Improve the Performance of Sweet Sorghum Grown in a Mo-Contaminated Soil. Journal of Fungi 6: 44 DOI 10.3390/jof6020044.

Peer) reviewing PDF | (2021:01:57095:2:1:NEW 17 Jun 2021) 
564 Shi ZY, Zhang LY, Li XL, Feng G, Tian CY, Christie P. 2007. Diversity of arbuscular

565

566

567

568

569

570

571

572

573

574

575

576

577

578

579

580

581

582

583

584

585

586

587

588

589

590

591

592

593

594

595

596

597

598

599

600

601

602

mycorrhizal fungi associated with desert ephemerals in plant communities of Junggar Basin, northwest China. Applied Soil Ecology 35: 10-20 DOI 10.1016/j.apsoil.2006.06.002.

Song G, Chen R, Xiang W, Yang F, Zheng S, Zhang J, Zhang J, Lin X. 2015. Contrasting effects of long-term fertilization on the community of saprotrophic fungi and arbuscular mycorrhizal fungi in a sandy loam soil. Plant, Soil and Environment 61: 127-136 DOI 10.17221/999/2014-pse.

Stackebrandt E, Goebel BM. 1994. Taxonomic Note: A Place for DNA-DNA Reassociation and 16S rRNA Sequence Analysis in the Present Species Definition in Bacteriology. International Journal of Systematic Bacteriology 44: 846-849 DOI 10.1099/00207713-44-4-846. Sturmer SL, Siqueira JO. 2011. Species richness and spore abundance of arbuscular mycorrhizal fungi across distinct land uses in Western Brazilian Amazon. Mycorrhiza 21: 255267 DOI 10.1007/s00572-010-0330-6.

\section{Sun XF, Su YY, Zhang Y, Wu MY, Zhang Z, Pei KQ, Sun LF, Wan SQ, Liang Y. 2013.}

Diversity of arbuscular mycorrhizal fungal spore communities and its relations to plants under increased temperature and precipitation in a natural grassland. Chinese Science Bulletin 58: 4109-4119 DOI 10.1007/s11434-013-5961-5.

Tian YQ, Gao Q, Zhang ZC, Zhang Y, Zhu K. 2009. The advances in study on plant photosynthesis and soil respiration of alpine grasslands on the Tibetan Plateau. Ecology and Environmental Sciences 18: 711-721 DOI10.16258/j.cnki.1674-5906.2009.02.067. van der Heijden MG, Klironomos JN, Ursic M, Moutoglis P, Streitwolf-engel R, Boller T, Wiemken A, Sanders LR. 1998. Mycorrhizal fungal diversity determines plant biodiversity, ecosystem variability and productivity. Nature 396: 69-72 DOI 10.1038/23932.

van der Heijden MGA, Martin FM, Selosse MA, Sanders IR. 2015. Mycorrhizal ecology and evolution: the past, the present, and the future. New Phytol 205: 1406-1423 DOI 10.1111/nph.13288.

van der Heijden MGA. 2004. Arbuscular mycorrhizal fungi as support systems for seedling establishment in grassland. Ecology Letters 7: 293-303 DOI 10.1111/j.1461-0248.2004.00577.x. Wang B, Qiu YL. 2006. Phylogenetic distribution and evolution of mycorrhizas in land plants. Mycorrhiza 16: 299-363 DOI 10.1007/s00572-005-0033-6.

Wang L, Pokharel SS, Chen FJ. 2019. Arbuscular mycorrhizal fungi alter the food utilization, growth, development and reproduction of armyworm (Mythimna separata) fed on Bacillus thuringiensis maize. PeerJ 7: e7679 DOI 10.7717/peerj.7679.

Wang Q, Garrity GM, Tiedje JM, Cole JR. 2007. Naive Bayesian classifier for rapid assignment of rRNA sequences into the new bacterial taxonomy. Appl Environ Microbiol 73: 5261-5267 DOI 10.1128/AEM.00062-07.

\section{Wilson H. Johnson BR. Bohannan B, Pfeifer-Meister L, Mueller R, Bridgham SD. 2016.} Experimental warming decreases arbuscular mycorrhizal fungal colonization in prairie plants along a Mediterranean climate gradient. PeerJ 4: e2083 DOI 10.7717/peerj.2083.

Peer) reviewing PDF | (2021:01:57095:2:1:NEW 17 Jun 2021) 
603 Wu MJ, Yan YR, Wang YQ, Mao Q, Fu YL, Peng XH, Yang ZK, Ren JJ, Liu AR, Chen 604 SC, Ahammed GJ. 2021. Arbuscular mycorrhizal fungi for vegetable (VT) enhance resistance 605 to Rhizoctonia solani in watermelon by alleviating oxidative stress. Biological Control 152:

606104433 DOI 10.1016/j.biocontrol.2020.104433.

607 Wu QS, Zou YN. 2010. Beneficial roles of arbuscular mycorrhizas in citrus seedlings at

608 temperature stress. Scientia Horticulturae 125: 289-293 DOI 10.1016/j.scienta.2010.04.001.

609 Xiang XJ, Gibbons SM, He JS, Wang C, He D, Li Q, Ni YY, Chu HY. 2016. Rapid response 610 of arbuscular mycorrhizal fungal communities to short-term fertilization in an alpine grassland 611 on the Qinghai-Tibet Plateau. PeerJ 4: e2226 DOI 10.7717/peerj.2226.

612 Yang C, Hamel C, Schellenberg MP, Perez JC, Berbara RL. 2010. Diversity and

613 Functionality of Arbuscular Mycorrhizal Fungi in Three Plant Communities in Semiarid

614 Grasslands National Park, Canada. Microbial Ecology 59: 724-733 DOI 10.1007/s00248-009-

615 9629-2.

616 Yang HS, Koide RT, Zhang Q. 2016. Short-term waterlogging increases arbuscular

617 mycorrhizal fungal species richness and shifts community composition. Plant and Soil 404: $373-$

618384 DOI 10.1007/s11104-016-2850-0.

619 Yang HS, Zang YY, Yuan YG, Tang JJ, Chen X. 2012. Selectivity by host plants affects the

620 distribution of arbuscular mycorrhizal fungi: evidence from ITS rDNA sequence metadata. BMC

621 Evolutionary Biology 12: 50 DOI 50. 10.1186/1471-2148-12-50.

622 Yang W, Zheng Y, Gao C, Duan JC, Wang SP, Guo LD. 2016. Arbuscular mycorrhizal

623 fungal community composition affected by original elevation rather than translocation along an

624 altitudinal gradient on the Qinghai-Tibet Plateau. Scientific Reports 6: 36606 DOI

$62510.1038 /$ srep36606.

626 Yang W, Zheng Y, Gao C, He XH, Ding Q, Kim YC, Rui YC, Wang SP, Guo LD. 2013. The

627 arbuscular mycorrhizal fungal community response to warming and grazing differs between soil

628 and roots on the Qinghai-Tibetan Plateau. Plos One 8: e76447 DOI

629 10.1371/journal.pone.0076447.

630 Zhang F, Zou YN, Wu QS, Kuca K. 2019. Arbuscular mycorrhizas modulate root polyamine

631 metabolism to enhance drought tolerance of trifoliate orange. Environmental and Experimental

632 Botany 171: 103926 DOI 10.1016/j.envexpbot.2019.103926.

633 Zhang ZF, Zhang JC, Xu GP, Zhou LW, Li YQ. 2019. Arbuscular mycorrhizal fungi improve

634 the growth and drought tolerance of Zenia insignis seedlings under drought stress. New Forests

635 50: 593-604 DOI 10.1007/s11056-018-9681-1.

636 Zhao H, Li XZ, Zhang ZM, Zhao Y, Yang JT, Zhu YW. 2017. Species diversity and drivers

637 of arbuscular mycorrhizal fungal communities in a semi-arid mountain in China. PeerJ 5: e4155

638 DOI $10.7717 /$ peerj.4155. 


\section{Figure 1}

Figure 1. The influence of warming on AMF richness .

CK means the treatment of control check and OTC means the treatment of warming by opentop chamber. Shared means the treatment of CK and OTC in share. The similarity level was $97 \%$. The data were statistically analyzed by ANOVA (warming: $\mathrm{F}=7.509, P=0.052$ ).

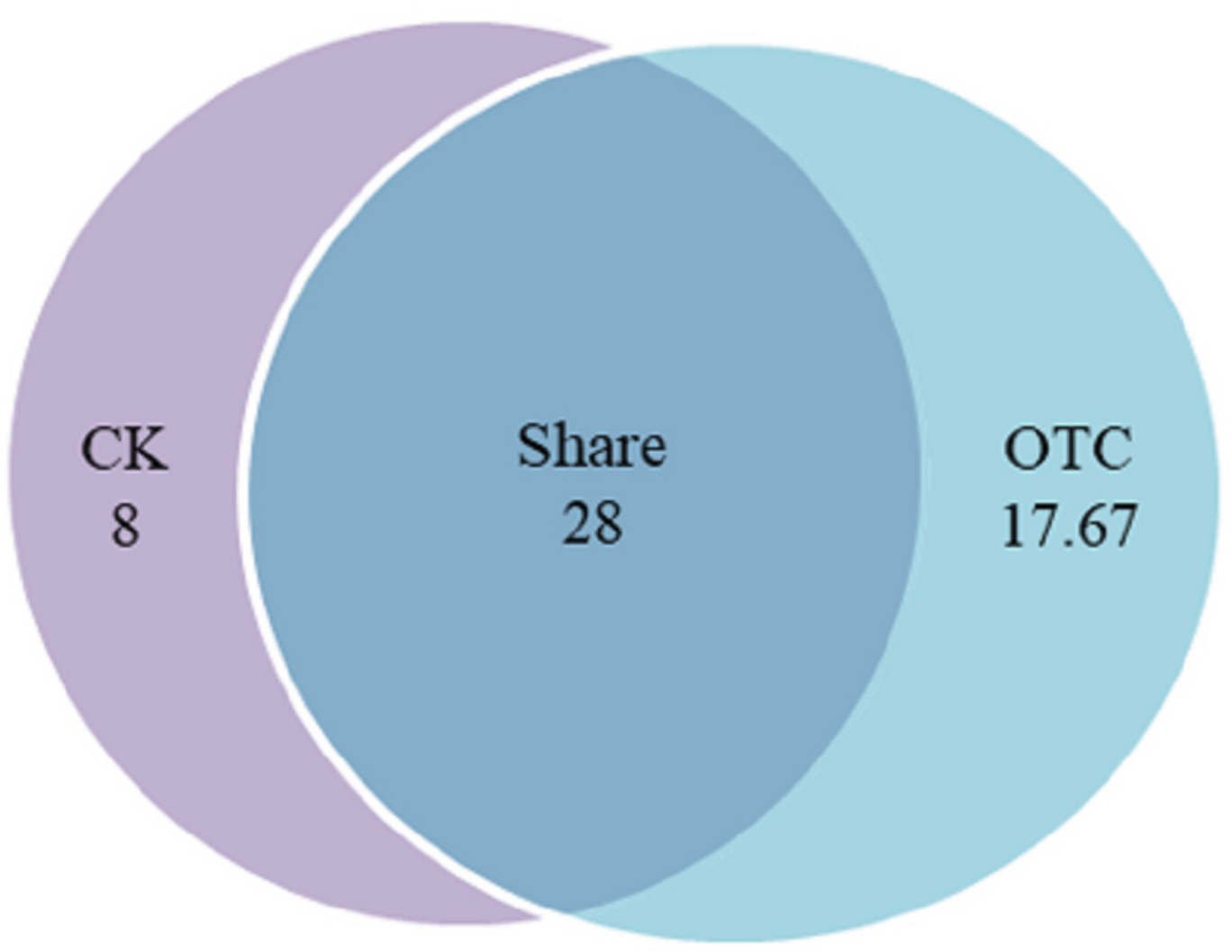




\section{Figure 2}

Figure 2. AMF diversity index at the level of OTUs based on different elevations by warming.

Error bars represent the standard error of the mean. Different lowercase letters above each column indicate significant difference, $P<0.05$. The data were statistically analyzed by ANOVA (elevations: $F=15.387, P=0.000 * *$; warming: $F=1.347, P=0.263$;

elevations $\times$ warming: $\mathrm{F}=3.874, P=0.029 *$ ), Shannon index (elevations: $\mathrm{F}=2.805, P=$ 0.073; warming: $\mathrm{F}=0.682, P=0.421$; elevations $\times$ warming: $\mathrm{F}=2.358, P=0.110$ ), Simpson evenness index (elevations: $\mathrm{F}=0.768, P=0.529$; warming: $\mathrm{F}=0.471, P=0.502$; elevations $x$ warming: $\mathrm{F}=1.594, P=0.230$ ), Ace index (elevations: $\mathrm{F}=3.369, P=0.045 *$; warming: $\mathrm{F}=0.047, P=0.832$; elevations $\times$ warming: $\mathrm{F}=1.578, P=0.234$ ). 

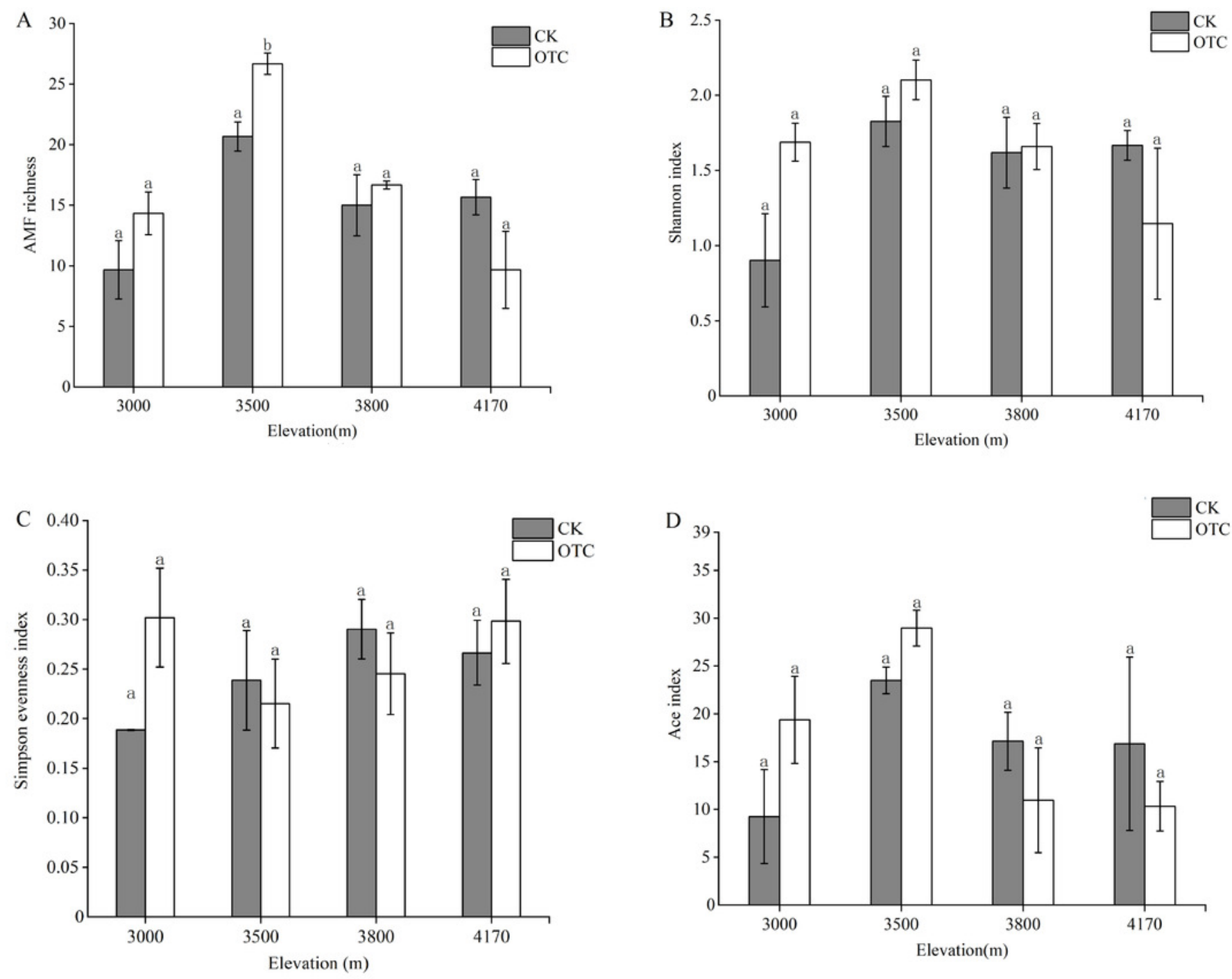
Figure 3

Figure 3. Nonmetric multidimensional scaling (NMDS) of the influence of warming on AMF community at the level of OTU.

The symbols represent the elevations of $3000 \mathrm{~m}, 3500 \mathrm{~m}, 3800 \mathrm{~m}$, and $4170 \mathrm{~m}$. CK means the treatment of control check and OTC means the treatment of warming with open-top chamber.

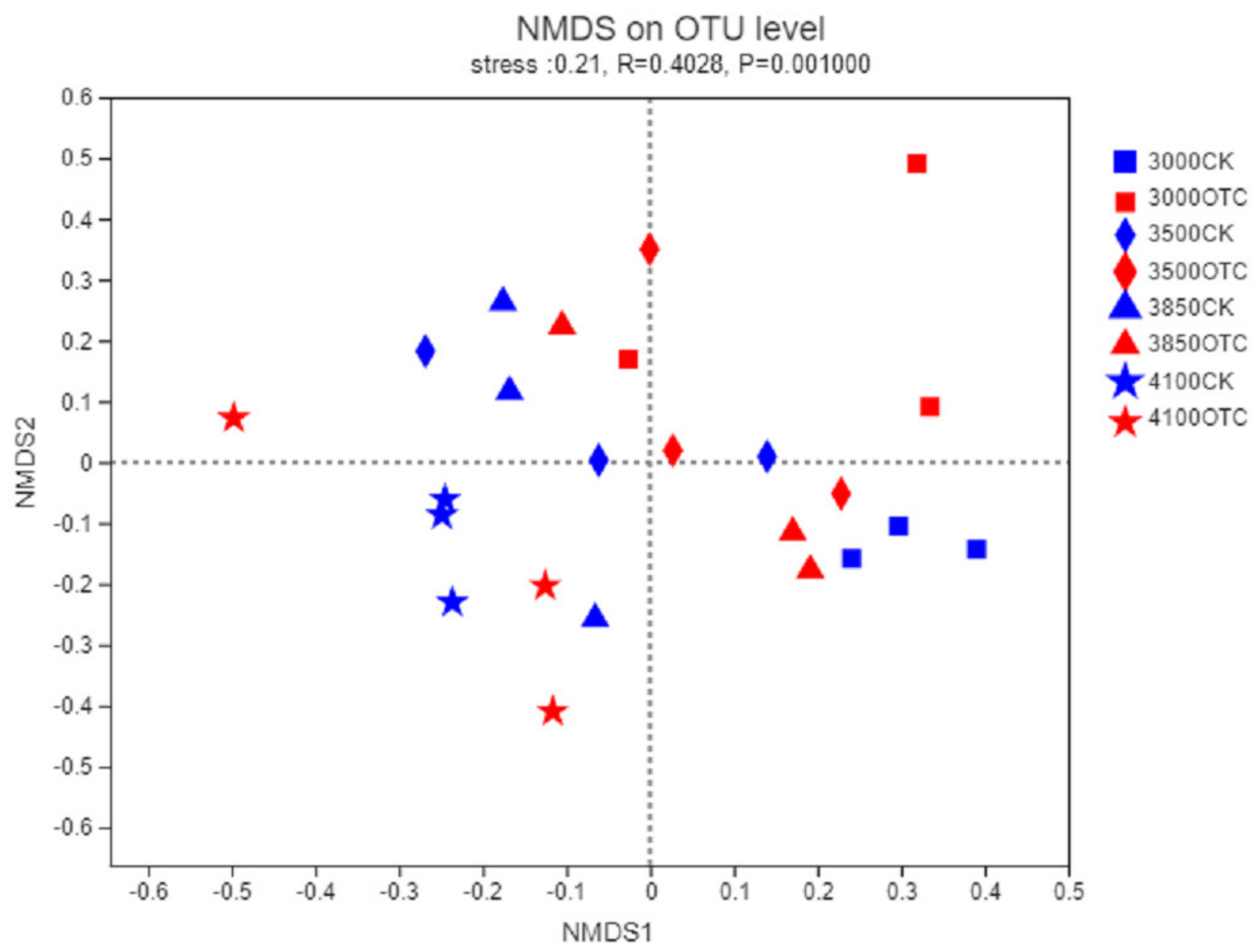


Figure 4

Figure 4. The influence of warming on RDA analysis at the level of genus based on different elevations.

CK means the treatment of control check and OTC means the treatment of warming with Open-top chamber. A, B, C, and D represent the RDA analysis at $3000 \mathrm{~m}, 3500 \mathrm{~m}, 3800 \mathrm{~m}$, and $4170 \mathrm{~m}$, respectively.

RDA on Genus level
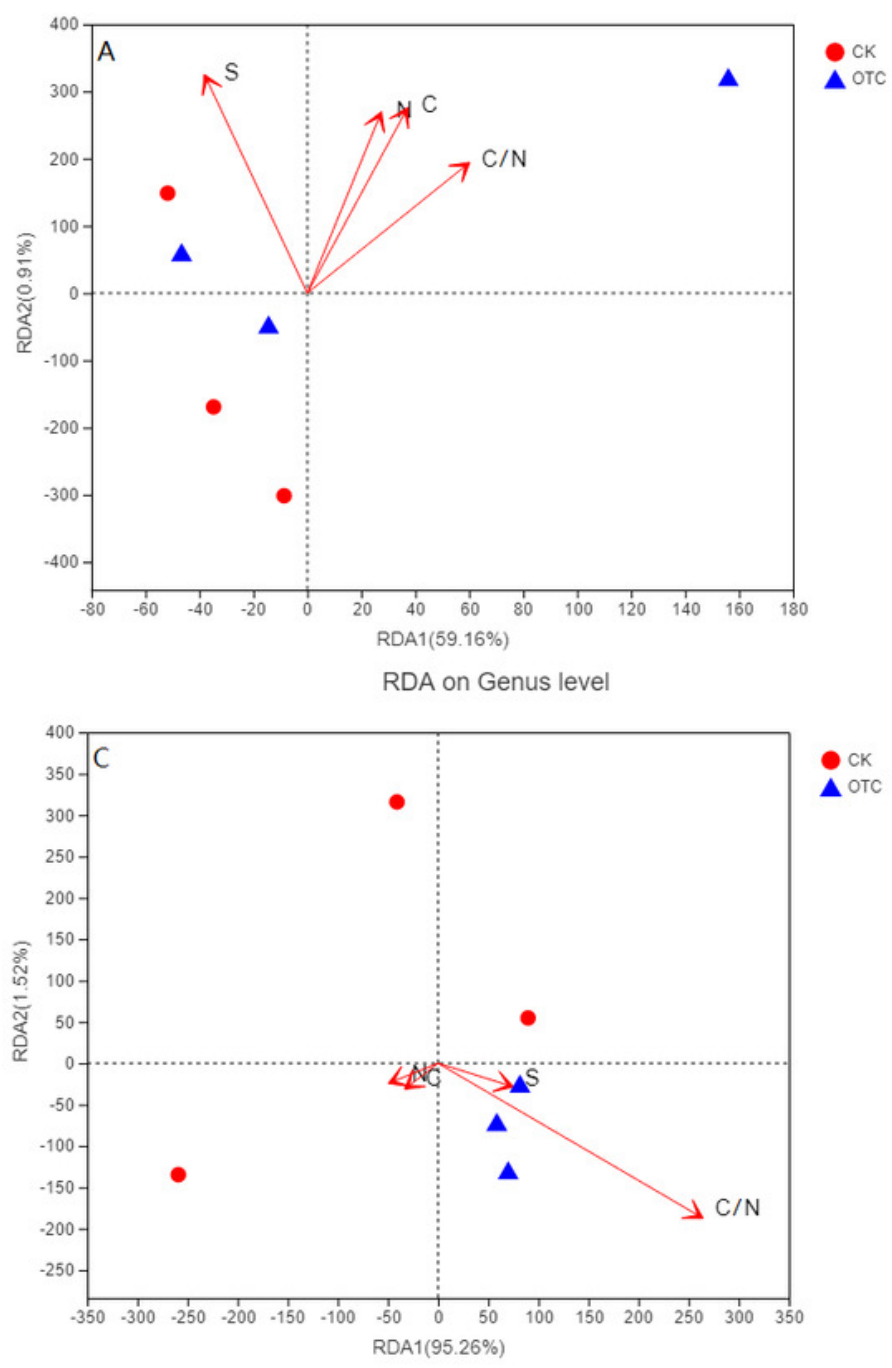

RDA on Genus level

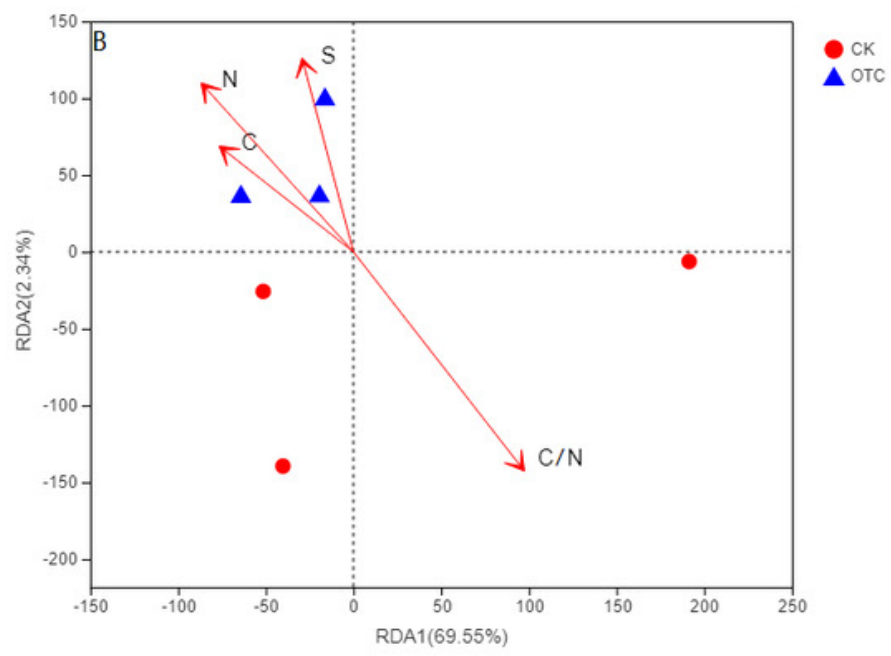

RDA on Genus level

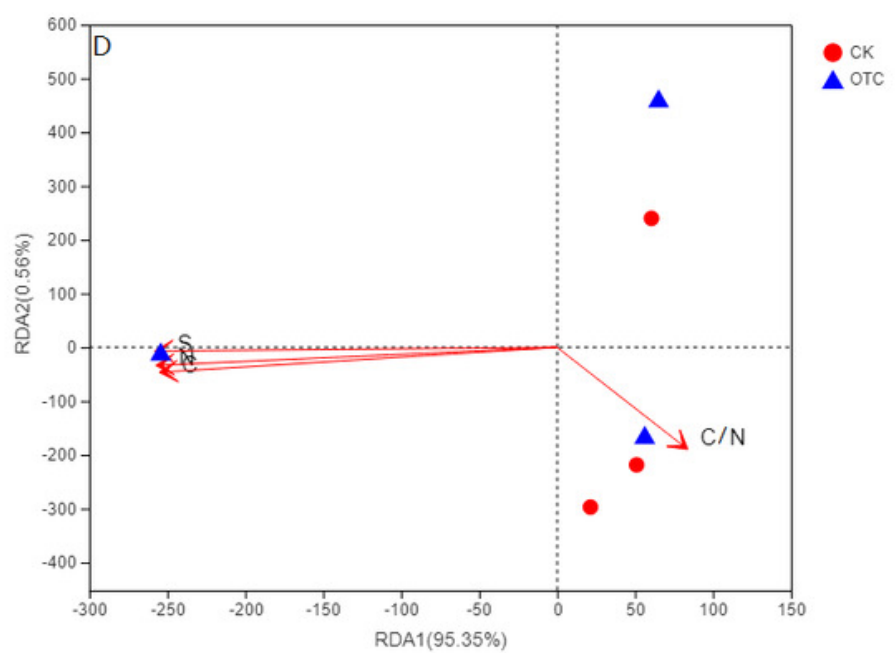




\section{Table $\mathbf{1}$ (on next page)}

Table 1. The sampling sites and coordinates based on different elevations on the Qinghai-Tibet Plateau. 
1

\begin{tabular}{|c|c|c|c|}
\hline Elevation & Sample location & longitude & latitude \\
\hline $3000 \mathrm{~m}$ & Near the Redstone Observation Deck & $\mathrm{E} 102^{\circ} 02^{\prime} 3.42^{\prime \prime}$ & $\mathrm{N} 29^{\circ} 50^{\prime} 36.49^{\prime \prime}$ \\
\hline $3500 \mathrm{~m}$ & Near the Yajiageng Timber Checkpoint & $\mathrm{E} 102^{\circ} 02^{\prime} 9.50^{\prime \prime}$ & $\mathrm{N} 29^{\circ} 51^{\prime} 42.90^{\prime \prime}$ \\
\hline $3800 \mathrm{~m}$ & Near the rock & $\mathrm{E} 102^{\circ} 01^{\prime} 2.30^{\prime \prime}$ & $\mathrm{N} 29^{\circ} 53^{\prime} 20.80^{\prime \prime}$ \\
\hline $4170 \mathrm{~m}$ & Go up the Yajiageng Boundary Monument for $1 \mathrm{~km}$ & $\mathrm{E} 102^{\circ} 0^{\prime} 42.50^{\prime \prime}$ & $\mathrm{N} 29^{\circ} 54^{\prime} 26.70^{\prime \prime}$ \\
\hline
\end{tabular}

2 


\section{Table 2 (on next page)}

Table 2. The influence of warming on AMF richness based on different elevations.

Notes: CK means the treatment of control check and OTC means the treatment of warming by open-top chamber. Shared means the treatment of CK and OTC in share. 


\begin{tabular}{|c|c|c|c|c|c|c|c|c|c|c|c|c|c|}
\hline \multirow{3}{*}{ Order } & \multirow{3}{*}{ Family } & \multirow{3}{*}{ Genus } & \multirow{3}{*}{ shared } & \multicolumn{2}{|c|}{ treatments } & \multicolumn{8}{|c|}{ Elevations } \\
\hline & & & & \multirow{2}{*}{ CK } & \multirow{2}{*}{ OTC } & \multicolumn{2}{|c|}{$3000 \mathrm{~m}$} & \multicolumn{2}{|c|}{$3500 \mathrm{~m}$} & \multicolumn{2}{|c|}{$3800 \mathrm{~m}$} & \multicolumn{2}{|c|}{$4170 \mathrm{~m}$} \\
\hline & & & & & & CK & OTC & CK & OTC & CK & оTC & CK & OTC \\
\hline \multirow[t]{3}{*}{ Archaeosporales } & Ambisporaceae & Ambispora & 1.33 & 1.67 & 1.67 & 0 & 0 & 0.33 & 1 & 0.67 & 1 & 1 & 0 \\
\hline & Archaeosporaceae & Archaeospora & 3 & 4 & 4.33 & 2.67 & 2.67 & 3 & 1 & 0.67 & 1.33 & 1 & 0.33 \\
\hline & Unclassified & Unclassified & 0.33 & 0.33 & 0.33 & 0 & 0 & 0 & 0 & 0.33 & 0.33 & 0 & 0 \\
\hline Diversisporales & Acaulosporaceae & Acaulospora & 9 & 10.67 & 12.33 & 4.33 & 4.67 & 6.33 & 8 & 5 & 5 & 7 & 4 \\
\hline Glomerales & Glomeraceae & Glomus & 12 & 13.67 & 20.33 & 2 & 4.33 & 9.67 & 15.33 & 6 & 8.33 & 3.67 & 3 \\
\hline Paraglomerales & Paraglomeraceae & Paraglomus & 0 & 0.33 & 0.33 & 0 & 0.33 & 0 & 0 & 0 & 0 & 0.33 & 0 \\
\hline Unclassified & Unclassified & Unclassified & 1.33 & 5.33 & 6.33 & 0.67 & 2.33 & 1.33 & 1.33 & 2.33 & 0.67 & 2.67 & 2.33 \\
\hline
\end{tabular}




\section{Table 3(on next page)}

Table 3. The influence of warming on the relative abundance of AMF based on different elevations.

Notes: CK means the treatment of control check and OTC means the treatment of warming by open-top chamber. Shared means the treatment of CK and OTC in share. 
1

\begin{tabular}{|c|c|c|c|c|c|c|c|c|c|c|}
\hline \multirow{3}{*}{ Order } & \multirow{3}{*}{ Family } & \multirow{3}{*}{ Genus } & \multicolumn{8}{|c|}{ Relative abundance $/ \%$} \\
\hline & & & \multicolumn{2}{|c|}{$3000 \mathrm{~m}$} & \multicolumn{2}{|r|}{$3500 \mathrm{~m}$} & \multicolumn{2}{|c|}{$3800 \mathrm{~m}$} & \multicolumn{2}{|c|}{$4170 \mathrm{~m}$} \\
\hline & & & CK & отC & CK & оTC & CK & OTC & CK & отC \\
\hline \multirow[t]{3}{*}{ Archaeosporales } & Ambisporaceae & Ambispora & 0 & 0 & 0.0490 & 0.0523 & 0.2286 & 0.0294 & 0.3756 & 0 \\
\hline & Archaeosporaceae & Archaeospora & 0.8361 & 1.2770 & 0.4115 & 0.0523 & 0.1110 & 0.0327 & 0.0555 & 0.5814 \\
\hline & Unclassified & Unclassified & 0 & 0 & 0 & 0 & 0.0621 & 0.0196 & 0 & 0 \\
\hline Diversisporales & Acaulosporaceae & Acaulospora & 19.6551 & 32.8304 & 38.9477 & 28.3297 & 37.8633 & 22.0295 & 53.9715 & 55.3139 \\
\hline Glomerales & Glomeraceae & Glomus & 79.4761 & 65.1349 & 60.5559 & 71.3894 & 60.8956 & 75.6614 & 44.0003 & 36.4655 \\
\hline Paraglomerales & Paraglomeraceae & Paraglomus & 0 & 0.0033 & 0 & 0 & 0 & 0 & 0.0065 & 0 \\
\hline Unclassified & Unclassified & Unclassified & 0.0327 & 0.7545 & 0.0359 & 0.1764 & 0.8394 & 2.2274 & 1.5906 & 7.6393 \\
\hline
\end{tabular}

2 


\section{Table 4(on next page)}

Table 4. The influence of warming on the occurrence frequency of AMF based on different elevations.

Notes: CK means the treatment of control check and OTC means the treatment of warming by open-top chamber. Shared means the treatment of CK and OTC in share. 


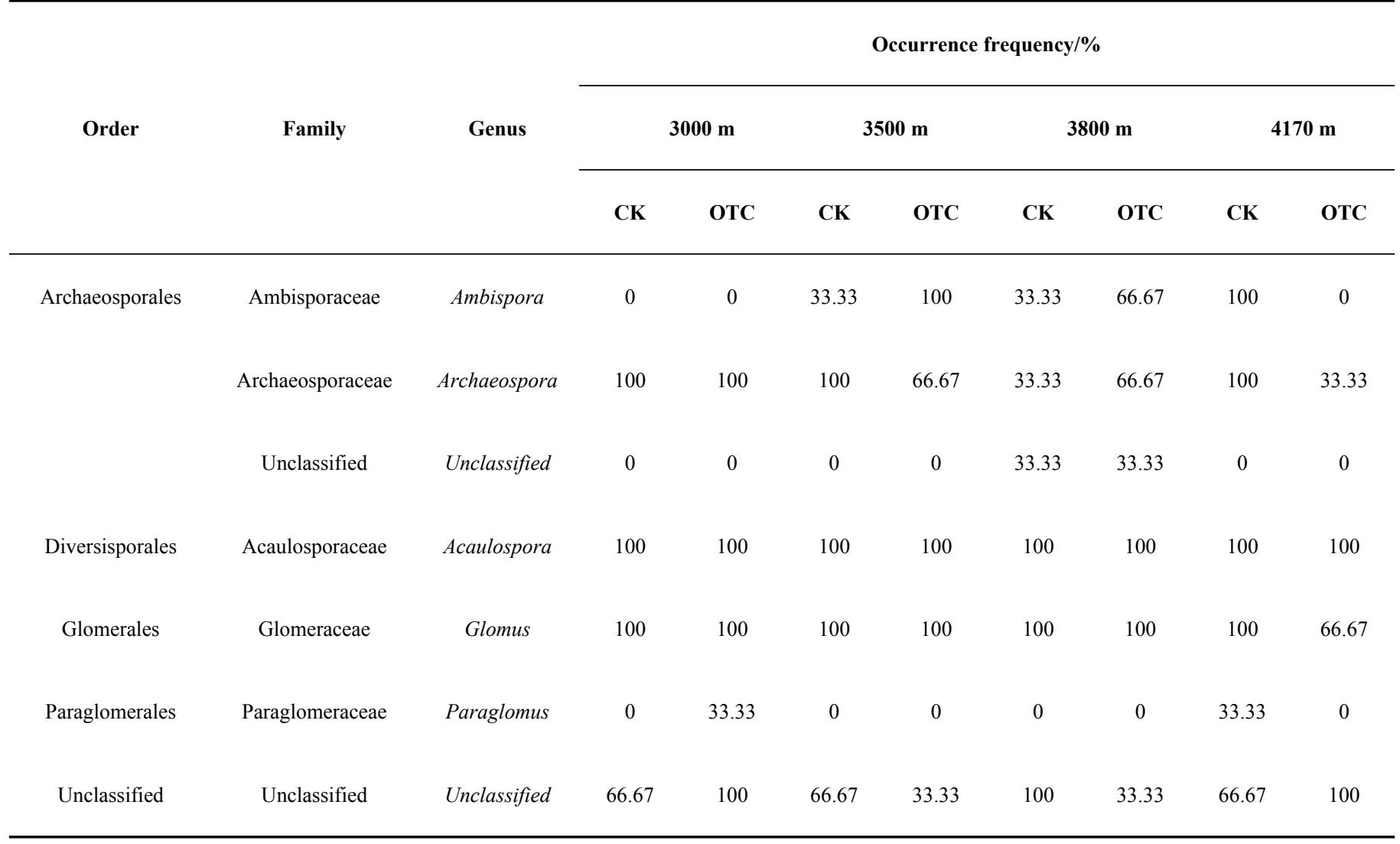

